\title{
Employment, Foreing Direct Investment and Challenges for Government Reform
}

\author{
Emir I.Hajdini \\ PHD Candidate, European University of Tirana, Albania. \\ Lector at Luarasi University, Tirana, Albania. \\ E-MAIL: ehajdini@gmail.com
}

\begin{abstract}
This article aims at indetifying the tendencies of foreing direct investments (now on FDI) wether any FDI is productive or not for the economy of the host country. As regards the methodology, can be said that the literature of the FDI attraction field is being analized, which encopases the preference toward the tipology of investments. FDl's attraction is crucial for countries with small economy, like Albania, especially on difficult financial times. However, not all the investments are beneficial for the host country.
\end{abstract}

Keywords: Employment in Albania, FDI, transition economy, government reform.

\section{Introduction}

Foreign Direct Investment is an integral part of an open economical system and a major katalisator of economic development. However, the benefits of FDI do not happen automatically and not disperse evenly among communities. National politics and the international structure of investment do matter for the attraction of FDl's into an ever growing number of developing countries and for a better absorption of the positive potential of those investments into sustainable growth. Challenges mainly are on the side of host countries, which have to create an open, transparent environment, that is clear and effective politics for the attraction of such investments and to build human and instructional infrastructure for the proper implementation of such politics. The role FDl's plays for guiding economic development and economic growth has ever been a contested one. Since the beginning there have been viewpoints in favor and against FDI. Some authors, argues that FDI led to economic growth and increase of productivity and hence to economic development, but others note the risk of FDI in destroying local capacities or over- exploiting the natural resources. There has been an increase of FDI into developing countries noted recently, although concentrated in certain countries, reflecting economic wealth and barriers to trade.

However, the decision making factors of FDI and as a consequence also the perspective of development dictated by FDI have changed over the time. As the barriers to trade and investment do have an impact to attracting FDls, the later are in the search for countries in the web of global production processes, hence in need for countries with good economic foundations such as: size of the market, adequate human resources, decent infrastructure and good technological local capacities.

Nonetheless, as countries have begun to understand the positive effect of FDl's, a diverse perception about the role of FDI on sustainable development has risen among the academic community, perceiving the impact of FDI not only positive or negative, but the effect varies on typology of FDl's, firm characteristics, economic conditions and host countries politics.

The type and sequence of general and specific policies in areas that covers investment, trade, innovation and human resources are considered as crucial within the link FDI and development. As FDI are superior in terms of capital and technology, the spillover effect into the development does not happen automatically. The suitable politics for attracting FDl's include: a) building human resources, b) building infrastructure and technological capacities, $c$ ) increase the absorption capacities to catch the spillover effect created by the productivity potential of FDl's. Countries have always used general and specific policies to reach the point where FDl's work for development.

As a conclusion, one can note that a major change has happened in FDl's liberalization and nowadays FDl's are considered as more positive than a couple decades ago, while governments steadily perceives that their politics can influence the FDl's effects on economic development. 


\section{Choice of Location}

Multinational Companies (MCN) faces a lot options when it comes to decide to locate their activities outside of the country of origin:FDI, exports, linceseing, or joint vention. The tradicional international business theories puts an emfasis on the advantages of onewership, location and the phenomena explained by OLI Paradigm (Dunning, 1993). Onwership advatanges are those that enables MNC to sucseed in a foreing market despite not knowing the market as well as the domestic companies and despite of the aditional costs of establishin a new branch. Onwership advantages are all about technological superiority and managerial know how. Location advantages are about what the host country can offer to MNC, i.e: market size, labor cost, good infrastrukture. Inner advatages drawn from OLI phenomena, when it is cheaper to invest than to export. While the onwnership and inners advantages are on the investor backyard, location advatages are specific for the host country. Even though the location advantages are becoming part of the investors decision making cause the host countries are continuesly competing for FDI.

\section{Enabling Enviroment of the Host Country}

There is a blossomly literature on the location advantages of FDI, UNCTAD, the UN Conference on Trade and Development presented on its ' 98 session the main reasons that now are founded sistematically in literature, clasifieing determinants factors of FDI in thre major groups: economic factors, the framework of policies for FDI and ease of doing business. According to the (Lee and Houde, 2000) analisis, six are the main location advantages, as follows:

Market size and the prespektive of extension. Factors like market size, prespective of extension, degree of development and income per capita on the host country are among the determinants of MNC when it comes to select location. Host Countries with large market, high economic growth and relative high degree of development are in a better position for MNC to exploit their onwership advantages thus to create economies of scale. FDI that are drawn by such advantages are consider as market oriented.

\section{Human and Natural Rescourcese}

The cost of the advantages but also the availability of human and natyral Rescources are the driving engine behind any FDI. FDI that are oriented toward exports seeks specifically comparative advantages that relate to cheap labor or abudant natyral rescources.

\section{Fisical, financial and technological infrastructure}

Differencies in infrastructure i.e transport, does influence the decision for investing in a not only among countries but among localities within the country. Most likely FDI chooses those locations that have better acsess to transport of course whith a minimal cost. Exept the quality of highways, trains, ports and airports, the level of telecomunication is continuosly more important caouse this sector has been subject to revolutionary change these decades. Human capital technological abilities in host country are a major factor in atracting FDI, (Ermir Hajdini, 2012).

\section{Openess to global trade}

Economic reforms, "open dors" politics as well as other measures to promote trade- through bilateral agrements or unilateral measures i.e the voluntary cuts on tarrif to trade, may atrract export oriented FDI. The strategic geografic position or even attractive geografic position assisted by importing abilities of the host country also the acsess to regional or global markets may result a major factor in atracting export oriented FDI

Political and Rregulatory Frame and Political Coherence.

General economical policies and social stability can establish the background for FDI policies, in Albanias case, legal and business enveroment transparent and well functioning are of an major importance because they lower the risk operating in a foreingh enviroment. Measures or rules relating to entering the market and proper functioning of foreing firms as well as the standarts for treatment of foreing firms are especially important in this aspect. Good corporate governance practises and fair ans transparent business practices, combined with fight against corruption- that create higher costs- influence positively not only to FDI "firstcomers" but also to the decission for riinvesting of profits. Also important are the policies that influence to the market functioning and structure, i.e kompatitionor trade policies even those politics that have to do with merger and acquisitions, privatizations and the coherence of those politics. Ending, a proper safeguard of investments is 
usually a minimun requirement for FDI. Therefore, where transparent procedures for resolving commercial disputes do not egzists and the egzisting rules are interpreted in a eneven way, FDI diverge.

\section{Discusion}

The above mentioned factors are somehow appealing to investments. However, the decision-making of an MNC to invest is subject of more complex and strategic consideration, including even the natyre of the profit that investor is expecting to make from the investment outside his country of origin. All in all the teory of "global integrated productivity", argues that: any part of the production chain is placed there where MNC makes the higher profit (UNCTAD 1999b). Several main reasons that motivate FDI are explained below:

FDI oriented towards rescources. The clasical reason why MNC search to invest in developing countries is the abunce of cheap production factors. However, the natyral rescources have been tradicionally the production factor that greatly attracted FDI, lately we are witnessing a rising tendence of cheap qualified labor as an most inportant factor in motivating FDI

Natyral Rescources. Multinational Kompanies (MNC) that operates in sectors like minning or in agroculture business of course that are attracted in those countries that have abudant natyral rescources. However, under the sight of sustainable development, must be noted that MNC have the tendency to export the majorit of their production and rely on imports of their inputs, thus contributing less on the economic activity of the host country. This tendency may be deteriorating by the import policies of the origin country, that well may lead to the discouragement of the local industril capacities.

Human Capital. FDI that seeks to benefit from cheap labor quite oftenly happens that MNC reacts toward the presure for hiegher wages in their country of origjin, sending the production proceses abroad. Furthermore, the benefits of FDI vs other forms of MNC invovelment in industries that are labor intensive are related to informality and scale disadvantaged that prevent host countries to benefit from their labor.

Market seeking FDI. The acess on the host country market for finished goods is an important reason to invest in manifacture sectors, especially in those cases where imports blocks the direct exports from countries of origin. Further reasons include: transportation costs, consumer taste, etc. Empirical data seems to suggest that local gathering gives boost to FDI to serve these magnified markets.

Eficency oriented FDI. MNC strategies to rise eficence through investments to developing countries go beyond realocation of labor intesive production. According to such strategy known as "component outscourcing", firms in developing countries undertake the obligation to supply MNC with fully finished goods whithin te trademark of MNC. The oppurtunities on behalf of the host country are greater than in those cases where there are just employment relations, but this also imply that host country firms are well developed technological skills. Another form of eficency driven FDI are the so called "horizontal" FDI, where the foreign capital establish companies according to the taste and standarts of the host country. Nonetheless, these FDI are limited to certain countries with large market and advance technologicaly.

FDI on search for Strategiic assets. Companies in search for assets having a comparative advantage- in most cases even a monopoly- do invests aiminig at those "strategic assets". in some public cases, MNC have invested out of their country of origin to obtain R\&D abilities. Developing countries may be atractive to such investments by developing their human capital and fisycal infrastrure. Another way through which MNC deeks to benefit strategic assets is the market dinamics that is the outcome of an hostile takeover.

The efect of FDI and specially the benefits Albania may enjoy from entry FDI, in major part are dependant on macroeconomic factors i.e balance between savings and investments, the degree of integration to the international financial sistem. VIS a vis to the balance betwen investments and savings a diferentiation must be made among those developing countries with enough savings to finance capital formation with optimal economic terms and those countries that can not achieve that. A second category is been made betwen those countries that theoretically have unlimited acsess to financial marke to finance its corrent account deficit and countries that do not have this opportunity.

Possibile channels through which FDI can influence the macroeconomic performance and as such economic groawth can be divided in thre categories: a) a surplus in total fonds for domestic investments, b) unlimited and stable financial means rather than credit or portofolio invesment, and c) contributes to the global integration, generates more extremities or create safe ground for structural reforms. However, we mustt note that the benefits from a dhe $b$ are generic and happens indipendetly of investment nationality. FDI indirectlly helps in achiving points a ande $b$ through additional rescources for credit finance or contribution toward a stabile econo-social climate. 
As shown above, the benefits for rising funds through posible investment depend on ountry ability for acsess to global or regional finance.

The combination betwen local savings and a relativelly unlimited acsess to finance internationally oftelly can be found in transition economies like ours. Policy- makers and companies must apreciate FDI in terms of an optimal mix betwen debit and credit to finance economic groawth. FDI are usually considered as an stable rescource of funds rather than portofolio investments or short term credit. for as long as FDI bring macroeconomic advantages beyond specific benefits, these benefits must be executed evenly notwithstanding the macroeconomic situation of the country.

\section{Economic Costs of FDI}

Economic costs of FDI or of foreing company presence can be outlined as any loss in social wealthcare of our country. However this "bold" statement rises conceptual problematics for as long FDI oftenly happend in the verge or contribute to radical economic referms, which may have pozitive or negative impact. As an example, if FDI are handeled as a tool for development therefore would be no room for any critics.

Furthemore, it is important that the distinction is made betwen net costs. for example, for improuving its economic performance, FDI must firstly impact its way to the egzisting structures and practises and it is expected that some economic actors to face a deterioration of their status. Policy-makers of our country must carefully evaluate the situation and balance social costs or any other costs coused by FDI with benefits from the invedtment. Only in rare cases of withdrawn, policymakers concentrated their FDI policy esclusively in cost reduction.

As a conclusion, the need to consider general costs in long term is important. Local authorities but also the public opinion that asses only the negative impact in shorter term of FDI must take into consideration the long term impact of FDI in economy and such clarification must be made always. It is clear that FDI rises the macroeconomic productivity and doubtless there might be short term term shortages, unemloyment etc but with flexibility and adaptive policies in host economy, the long term impact in social wellfare would be positive. in absense of an adaptive aproach from the labor market, the negative effect would last longer but this can not be seem as a FDI cost but rather as a deficit of the host country.

\section{References}

[1] Cevis, I. and Camurdan, B. (2009). The Economical Determinants of Foreign Direct Investment (FDI) in Developing Countries and Transition Economies, e-Journal of NeW World Sciences Academy, 4(3), 210-223.

[2] Combes, J.-L., Kinda, T. and Plane, P. (2011). Capital Flows, Exchange Rate Flexibility, and the Real Exchange Rate, working paper No. WP/11/9, International Monetary Fund, Washington, D.C., January 2011.

[3] Deichmann, J.I., Eshghi, A., Haughton, D.M., Sayek, S. and Teebagy, N.C. (2003). Foreign Direct Investment in the Eurasian Transition Statesll, Eastern European Economics, 41(1), 5-34.

[4] Faras, R.Y. and Ghali, K.H. (2009). Foreign Direct Investment and Economic Growth: The Case of the GCC Countries, International Research Journal of Finance and Economics, 29, 134-145.

[5] Globerman, S. and Shapiro, D. (2003). Governance infrastructure and US foreign direct investment, Journal of International Business Studies, 34(1), 19-39.

[6] Hooley, G., Cox, T., Shipley, D., Fahy, J., Beracs, J. and Kolos, K. (1996). Foreign Direct Investment in Hungary: Resource Acquisition and Domestic Competitive Advantage, Journal of International Business Studies, 27(4), 683-709.

[7] Safarian, A.E. (1973). Perspectives on Foreign Direct Investment from the Viewpoint of a Capital Receiving Country, The Journal of Finance, 28(2), 419-438.

[8] Sethi, D., Guisinger, S.E., Phelan, S.E. and Berg, D.M. (2003). Trends in Foreign Direct Investment Flows: A Theoretical and Empirical Analysis, Journal of International Business Studies, 34(4), 315-326.

[9] Soon, T.-W. dhe Stoever, W.A. (1996). Foreign Investment and Economic Development in Singapore: A PolicyOriented Approach, The Journal of Developing Areas, 30(3), 317-340. 
[10] Szanyi, M. (1998). Experiences ëith Foreign Direct Investment in Eastern Europe: Advantages and Disadvantages II, Eastern European Economies, 36(3), 28-48.

[11] United Nations Conference on Trade and Development (UNCTAD) (2010). World Investment Report 2010, vizituar: 02.12.2011. Available at:

[12] http://www.unctad.org/templates/webflyer.asp?docid=13423\&intltemID=2068\&lang=1.

[13] United Nations Conference on Trade and Development (UNCTAD) (2011). Global Investment Trends Monitor No. 5, vizituar: 02.12.2011. Available at

[14] : http://www.unctad.org/en/docs//webdiaeia20111_en.pdf.

Table 1. Specific benefits from FDI

\begin{tabular}{ll}
\hline Limited acsess & Unlimited acsess \\
To finance & To finance \\
\hline a) Fonds rise & b) Financial stability \\
c) Specific benefits from FDI & c) Specific benefits from FDI \\
c) Specific benefits from FDI & c) Specific benefits from FDI \\
\hline
\end{tabular}

